\title{
The Use of ICT among Pre-Service English Language Teachers
}

\author{
Tam Suet Yet \\ Universiti Putra Malaysia \\ 43400 UPM Serdang, Selangor Darul Ehsan, Malaysia \\ Tel: 601-2380-2938Ｅ-mail: suetyet@yahoo.com
}

Dr. Nooreen Binti Noordin (Corresponding author)

Faculty of Educational Studies, Universiti Putra Malaysia

43400 UPM Serdang, Selangor Darul Ehsan, Malaysia

Tel: 601-3667-0573 E-mail: nooyeen@yahoo.com

Received: February 4, 2017 Accepted: February 18, 2017 Published: February 20, 2017

doi:10.5296/ijele.v5i1.10779 URL: http://dx.doi.org/10.5296/ijele.v5i1.10779

\begin{abstract}
Information Communications and Technology (ICT) was first introduced through the Smart School project in 1997. Results from past studies on teachers' use of ICT were mixed whereby their confidence in using ICT and their use and integration of ICT in their classroom practice were incoherent. Hence, this study intends to investigate the confidence level and skills of current pre-service teachers in teaching the English language through the use of ICT. Forty six pre-service English language teachers were selected purposively from a local university and a teacher training college, based on these few criteria set within the limitations of this study. This atudy adopted and adapted the questionnaires from the ICT Integration Survey (Spazak, 2010) and Technological Pedagogical and Content Knowledge (TPACK) by Mishra and Koehler (2006). These questionnaires are adopted for the purpose of understanding the pre-service teachers' technological skills, as well as their content and pedagogical knowledge of English language teaching at the point in time when the data was collected. The data collected were analysed using the Statistical Packet for the Social Sciences (SPSS). Results showed that pre-service English language teachers are confident users of ICT, both for their own personal interests and to integrate ICT in their teaching.
\end{abstract}




\section{Macrothink}

International Journal of English Language Education

ISSN 2325-0887

2017, Vol. 5, No. 1

However, it is also found that pre-service teachers are skilled in ICT because they have been exposed to it since young. Further results that have emerged from this study revealed that there is no relationship between the time used in ICT and the confidence or skills in using ICT.

Keywords: Digital natives, New literacies, Pre-service teachers, ICT use 


\section{Introduction}

Within the 21st century, the use of Information Communications and Technology (ICT) is paramount towards nation development due to the various social and economic networking opportunities provided through this aspect (Spazak, 2013). In meeting the demands of this challenge, the school shoulders a share of the responsibility towards providing opportunities for learners to learn and acquire ICT skills that would be helpful for their future. Hence, as a nationwide aspiration, the Ministry of Education has continuously upgraded and introduced various methods and approaches for classroom practice, ranging from tools and software to professional development courses to train the in-service teachers (Moganashwari \& Parilah, 2013). Within the training of pre-service teachers in English as a Second Language (ESL), courses that incorporate ICT such as the Computer Assisted Language Learning (CALL) are included to expose teachers to the different tools and resources in developing ICT-based materials. Through these efforts, the classroom practices that incorporate ICT should be adequate towards preparing learners to achieve the desired outcome in utilizing ICT for professional benefits.

\subsection{Role of ESL Teachers}

The role of a teacher is crucial in ensuring students are well exposed and literate not only within the language skills of reading, writing, speaking and listening but also stay relevant to the continuous change in technologies that can affect the usage of the language skills. This includes the new forms of literacies that the Internet has brought, based on the varied layouts of information that students need to process beyond the current conventional methods. These literacies, known as new literacies (Lankshear \& Knobel, 2011), require both the traditional literacies, as found in the language skills, as well as ICT-related literacies such as digital literacy, information literacy and critical literacy (Churchill, 2009). This is because, one of the 21 st century learning outcomes for students is pitched towards innovation and creativity in order for them to be adaptable to changes that are alongside with the constant progress in the information and communication methods.

For ESL teachers, much preparation is needed as they bridge the gaps between their past experiences as students, where the value of their learning is not the same as the needs of the current student; with the prognosis on the knowledge that students need to acquire in order to adapt themselves in the future. Teachers are now shouldering the responsibility in utilizing the current content, technological and pedagogical knowledge (Pierson, 2001) to ensure the learning of the language and ICT exposure run concurrently to provide relevance to the learning objectives and authenticity to the real world. As a result, teachers are also required to be competent and have the right attitude towards ICT (Kadel, 2005) because the effectiveness of teachers to convey the content and ICT knowledge highly depends on teachers' beliefs, experiences, expected outcomes, levels of knowledge and the teaching and learning approaches (Thomas \& Stratton, 2006). This competency and attitude are similar to findings by Kirschner and Woperies (2003) which include the teachers' personal use of ICT to utilizing ICT in classrooms. 


\section{Malaysian Context}

Various studies done in the Malaysian context on the use of ICT in classrooms, from ESL to other subjects, have found ICT use a challenge in schools due to various internal and external reasons (Hafizoah, Haslinda \& Noor, 2004; Melor, 2007; Samuel \& Zaitun, 2007; Moganash \& Parilah, 2013). While ESL teachers have a positive attitude and are willing to integrate ICT in their lessons, (Melor, 2007; Samuel \& Zaitun, 2007; Abdul Rahim \& Shamsiah, 2008), their confidence and competence of use are found to be only competent in areas involving social correspondence such as emailing, or developing notes using Mircosoft Power Point. Hence, the use of ICT in classrooms by teachers in these studies are limited, where it serves as a tool to communicate their lessons. While the teachers are acknowledged to have difficulties in handling ICT, current novice and pre-service teachers are viewed to be competent to handle ICT as they have grown up with technological devices and the Internet. Prensky (2001) believes that these digital natives would provide an understanding of how students think and process information which would be different from the digital immigrants. He found that digital natives can multitask, are active in their learning, process information quickly and rely heavily on ICT to access information. These characteristics describe the confidence and competency of digital natives who are born after the 1980s, when ICT use boomed and developed until its current status as a necessity today.

Thus, within their professional parameters, these digital natives would be able to relate to not only the demands and consumption of the current students towards the use of ICT but also to utilize ICT in their teaching. Although pre-service teachers are yet to begin their professional practice, they are undoubtedly within the generation of students who had gone through the Smart School programme, where various ICT facilities such as computer labs and the Internet were made available for them. Currently, in their training to become a teacher, courses that integrate classroom practice with ICT such as Computer Assisted Language Learning (CALL) or Learning Management System (LMS) are being exposed to them. Teo, Wong and Chai (2008) found pre-service teachers have specific courses that are catered to deliver the ICT knowledge that they would need in the schools. As for the Internet, Wong, Ng, Mokhtar and Tang (2005) found that pre-service teachers have positive attitudes towards the use of ICT, especially the Internet, once they are experienced and spend longer hours using it.

Although there are still limited literature found on the use of ICT by pre-service teachers in their teaching practice within the ESL context in Malaysia, there are various studies done on pre-service teachers with ICT use throughout/in the literature. Gill, Dalgarno and Clarson (2015) found that pre-service teachers who have prior knowledge on ICT due to personal or social reasons may not be aware of its use in teaching. Some pre-service teachers feel that there is inadequate training on the pedagogical aspects of ICT use in classroom practice (Roblin, van Braak, Fisser \& Voogt, 2013). Hashemi (2013) reported in his study that teachers tend to be exposed to the technology tools needed to teach instead of the pedagogy or methodology to impart their knowledge of applying and handling technology tools as a teaching practice. Being inexperienced in class, pre-service teachers may not understand the nature and authentic setting of schools which could affect their ability to assess themselves in their use of ICT (Harris, Grandgenett \& Hofer, 2010). 


\subsection{Statement of the Problem}

There are two issues pertaining Prensky's claim that requires further investigation, especially within the Malaysian context. Firstly, Prensky believed that digital natives are more adept in using ICT. But, some researchers are beginning to argue his statement by providing statistics of some digital natives who are not as technologically savvy as they should be (Spazak, 2013). Based on Bandura's Social Cognitive Theory (1989), besides environment, the personal factor which is highly related to cognition plays a role in affecting the attitude of a person towards a certain element. Secondly, though the digital natives are confident and show positive attitudes in using ICT for their personal use, this does not necessarily mean that they are able to utilize, convey and use ICT in their teaching and learning context (Moganashwari \& Parilah, 2013). This is because there is a difference between knowing the knowledge and knowing how to transmit the knowledge to other people, depending on their social and cognitive capabilities. The second problem raised is crucial, not only to the in-service teachers but also the current pre-teachers. Since they are still in training, it is therefore important to find out the ICT-related knowledge they possess in order to evaluate if they are able to teach the skills and knowledge required within ICT.

\subsection{Aim of Study}

Therefore, this study aims to investigate the characteristics of the current pre-service teachers towards the use of ICT since there is a gap of time for similar studies done within this area; with studies done by Tang (2005), Melor (2007), Samuel and Zaitun (2007) as well as Abdul Rahim and Shamsiah (2008). Building on these studies, it is hoped that the findings can contribute to the understanding as well as project the extent of ICT implementation in class to be more enhanced than before. Moreover, it is also hoped that by comparing the findings of this study to past studies, there will be an observable pattern in terms of the training of pre-service teachers within Malaysia in the efforts to upscale their professional development when they are appointed as in-service teachers.

This study aims to investigate the ICT knowledge among the pre-service teachers. There are four research questions built for this study, whereby each has at least a sub-question to investigate the area further. These questions are:

1. What is the frequency of ICT exposure among the pre-service teachers as digital natives?

2. To what extent do pre-service teachers utilize the Internet?

3. What is the relationship between the length of time spent on the Internet with the confidence of pre-service teachers in using ICT in the classroom?

4. What is the relationship between the length of time spent on the Internet towards TPA

\section{Methods}

This study is a quantitative study which investigates the significant relationship between the 
digital native pre-service teachers towards their knowledge in the ICT literacy. Forty six pre-service teachers were selected using purposive sampling from a local university and teacher training college within the Peninsula Malaysia. There are three criteria set within this sampling in order to fulfill the aims of this study. Firstly, the pre-service teachers must be born after the 1980s, to fit to the characteristics of digital natives. Secondly, these pre-service teachers must be undergoing a TESL programme since the study involves the use of ICT within language classrooms where the four skills in language learning are emphasized to deliver a specific content of knowledge. Finally, the pre-service teachers must be in the final year as they would have experienced teaching in or the nature of the school environment through short internships, practicum or observations in schools. Most importantly, the pre-service teachers participated in this study did so voluntarily. Due to these criteria, the participants for this study is limited.

An adapted version of ICT Integration Survey (Spazak, 2013) and TPACK (Mishra \& Koehler, 2010) was given to the sample. The data collected were analysed using the Statistical Package for Social Science (SPSS) Version 12.0 Windows. The analysis was conducted using descriptive statistics, one way analysis of variance as well as multivariate analysis of variance (MANOVA). Both ANOVA and MANOVA has the confidence level set at $(\mathrm{p}=0.05)$.

The survey was divided into 3 sections, as found in Appendix 1. The first section (Section A) was the demographic information of the pre-service teachers. The second section (Section B) focuses on the usage and the integration of ICT based on several items proposed. The last section, which is Section C, needed pre -service teachers to rate their proficiency of the ICT skills using a 5-point Likert scale. Pre-service teachers are to choose between (1) no experience to (5) expert in being able to perform a technological task. The responses are keyed into SPSS and analyzed using Descriptive Analysis.

\section{Results}

Table 1. Stages in ICT Exposure

\begin{tabular}{|l|r|r|r|}
\hline & Frequency & Percent & $\begin{array}{c}\text { Cumulative } \\
\text { Percent }\end{array}$ \\
\hline before kindergarten & 5 & 10.9 & 10.9 \\
\hline in kindergarten & 10 & 21.7 & 32.6 \\
\hline in primary school & 18 & 39.1 & 71.7 \\
\hline in secondary school & 10 & 21.7 & 93.5 \\
\hline in university & 3 & 6.5 & 100.0 \\
\hline Total & $\mathbf{4 6}$ & $\mathbf{1 0 0 . 0}$ & \\
\hline
\end{tabular}

Table 1 shows the analysis of the earliest exposure to ICT for the digital native pre-service teachers. Based on Table 1, the stage where pre -service teachers are exposed to ICT the 
most is when they were in primary school $(\mathrm{f}=18, \mathrm{n}=46)$. This is followed by either when they were in secondary school $(\mathrm{f}=10, \mathrm{n}=46)$ or before they enter kindergarten $(\mathrm{f}=10, \mathrm{n}=46)$. Only 3 pre-service teachers were exposed to ICT when they have entered university while 5 pre-service teachers were exposed to ICT in kindergarten.

Table 2. Frequency and Percentage of Internet Usage among Pre-service Teachers

\begin{tabular}{|l|c|c|}
\hline Items & Frequency & Cumulative Percent \\
\hline Express ideas & 1 & 2.2 \\
\hline Information & 11 & 26.1 \\
\hline Reading news & 3 & 32.6 \\
\hline Playing games & 1 & 34.8 \\
\hline Make new friends & 1 & 37.0 \\
\hline Communicating friends & 8 & 54.3 \\
\hline Know world & 11 & 78.3 \\
\hline Shopping & 1 & 80.4 \\
\hline Downloading & 9 & 100.0 \\
\hline Total & 46 & \\
\hline
\end{tabular}

Table 2 shows the analysis of Internet usage by the pre-service teachers. Based on the analysis, the pre-service teachers use the Internet the most to search for information $(\mathrm{f}=11, \mathrm{n}$ $=46)$ such as on health, weather and other informative texts. Pre-service teachers also utilize the Internet to know about the things around the world $(f=11, n=46)$. These pre-service teachers also use the Internet for downloading purposes ( $\mathrm{f}=9, \mathrm{n}=46$ ) as well as communicating with their friends $(f=8, n=46)$. Other reasons for pre-service teachers to use the Internet is for reading the news ( $f=3, n=46)$, playing games ( $f=1, n=46$ ), shopping ( $f$ $=3, \mathrm{n}=46)$, making new friends $(\mathrm{f}=1, \mathrm{n}=46)$ and to express their own ideas freely $(\mathrm{f}=1, \mathrm{n}$ $=46)$.

Table 3. ANOVA to compare Time Spent on Internet and Confidence

\begin{tabular}{|l|c|c|c|c|c|}
\hline & Sum of Squares & df & Mean Square & F & Sig. \\
\hline & & & & & \\
\hline Between Groups & 3.429 & 5 & .686 & 1.100 & .376 \\
\hline Within Groups & 24.941 & 40 & .624 & & \\
\hline Total & 28.370 & 45 & & & \\
\hline
\end{tabular}

Table 3 shows a one-way between subjects ANOVA conducted to compare the effects of the time spent by pre-service teachers on the Internet towards their self- perceived confidence in using ICT to teach in classrooms. There are six conditions of time spent on the Internet which are (1) none at all, (2) less than an hour, (3) about $1-2$, (4) about $2-3$ hours, (5) about $3-4$ hours and lastly (6) more than 4 hours. There were no significant relationship between the 
amount of time spent on the Internet towards their confidence level to teach in classrooms $b$, using the $\operatorname{ICT}[\mathrm{F}(5,40)=1.10, p=0.376]$.

Table 4. MANOVA between the Time Spent on the Internet and TPACK

\begin{tabular}{|c|c|c|c|c|c|c|}
\hline \multicolumn{2}{|l|}{ Effect } & Value & $\mathrm{F}$ & Hypothesis df & Error df & Sig. \\
\hline \multirow{4}{*}{ TIME_COMPUTER } & Pillai's Trace & 4.321 & 1.591 & 180.000 & 45.000 & .034 \\
\hline & Wilks' Lambda & .000 & 2.002 & 180.000 & 30.077 & .013 \\
\hline & $\begin{array}{l}\text { Hotelling's } \\
\text { Trace }\end{array}$ & 102.507 & 1.936 & 180.000 & 17.000 & .057 \\
\hline & $\begin{array}{l}\text { Roy's Largest } \\
\text { Root }\end{array}$ & 55.497 & $13.874^{\mathrm{c}}$ & 36.000 & 9.000 & .000 \\
\hline
\end{tabular}

Table 4 below shows the Multivariate Tests table using the one-way MANOVA in determining the significance of the amount of time spent by these pre-service teachers on their computer in their Technological Pedagogical and Content Knowledge (TPACK). Based on the results from the table, it can be concluded that the pre-service teachers' TPACK is significantly dependent on the time they spent on the computer, with the significant value of $.01(p<.05)$.

\section{Discussion}

Research question 1 intends to find out how early was the exposure of the pre-service teachers in being constantly referred to as the digital natives. Based on the findings in Table 1, a majority of these pre-service teachers have been exposed to ICT before entering secondary school, demonstrating the importance of ICT being available to the pre-service teachers throughout their developmental stage. This importance is portrayed through the high cumulative percentage $(71.7 \%)$ of the pre-service teachers having been exposed to ICT since primary school. Comparing this to previous literature , Hence, as Prensky (2001) believed, these pre-service teachers should have the technological skills required to maneuver around with the tools and applications which can enhance their teaching. This finding provides the basis to an intertwined connection based on the following research questions which were aimed to discover the aspects within the teaching practice of these pre-service teachers that could be enhanced when integrated with their technological skills.

Thus, research question 2 intends to know what interests the pre-service teachers today when they explore the Internet. Based on the analysis of Table 2, it is possible to say that the pre-service teachers have the technological skills to search for information and know about other things that are happening around the world. This finding supports Prensky's (2001) argument that ICT, and especially the Internet has changed the way individuals learn about the world today. Most people, including the pre-service teachers in this study refer to the Internet in searching for information and various personal purposes. The fact that they are interested in the world depicts the cognitive aspect of the pre-service teachers which could be 
used in predicting the cognitive views of students and teachers in the future. They are more exposed to the world; securing their characteristics in being more adaptable to the changing demands of the global progress at large. Hence, information provided for students in the future would need to be of more value than those that they could find on their own through the Internet. By focusing on real world information, these pre-service teachers, it is expected that they should be able to connect the real world to the context of their classrooms, as argued by Harris, Grandgenett and Hofer (2010). Moreover, the findings from Table 2 support the findings from Wong, $\mathrm{Ng}$, Mokhtar and Tang (2005) whereby pre-service teachers are still responding positively towards the use of Internet. There is therefore a need to study and investigate further towards thus positive response to the Internet among the pre-service teachers, the skills in being able to search for information on the Internet and the teaching practice that these pre-service teachers can deliver in their lessons. The ability in searching for information from the Internet and their consumption of information supports Lankshear and Knobel's (2011) argument that these pre-service teachers have already acquired the new literacies themselves as they are able to mediate themselves through the various format and layout of texts to understand. But, how far can this acquired knowledge that these pre-service teachers have be conveyed and taught to students? Hence, it is important to take a step further in ensuring that the these pre-service teachers are not only equipped with the knowledge in teaching the students but to also be up-to-date with their ICT-related knowledge and information since their students may be on par with them due to the early exposure.

This argument is related to findings based on the third research question. Research question 3 intends to find out if there is a relationship between the time spent using the Internet and the confidence of these pre-service teachers in using the Internet in classroom to teach. Although pre-service teachers are avid users of the Internet, there is no significant relationship between the length of time they spent on the Internet with their self-perceived confidence in teaching their own classroom. This finding supports the claims made by Moganashwari and Parilah (2013) that although teachers use ICT aptly, they may not be confident in using it in classrooms, although these claims need to have further study on it. In fact, Moganashwari and Parilah's study was on in-service teachers, and yet, similar traits can be found in pre-service teachers. In expanding this perspective wider, this could be caused by two reasons. Firstly, the use of Internet by these pre-service teachers within this study is unable to be exploited for teaching purposes since there could be personal interests involved. This is because, as mentioned by Teo, Wong and Chai (2008), pre-service teachers are already given training in teaching using ICT, suggesting that these pre-service teachers are using ICT heavily. Hence, with the pre-service teachers being avid users of ICT, the results support the findings of the fourth research question. These pre-service teachers seem to have obtained a positive results within the TPACK. Yet, the result from this study pinpoints that there could be other aspects which affect pre-service teachers' confidence in using Internet in class. After all, the pre-service teachers may be trained in using the gadgets and tools related to ICT such as using certain software or programmes and not the integration of Internet into the classroom practice itself. This integration includes classroom control, instructional strategies as well as assessment and evaluation which these pre-service teachers may not have been trained in. Hence, even when they are spending more time in using ICT during their courses or training, 
it is unrelated to the important aspects of ICT use and confidence in using it. Therefore, it is important to develop a proper training for these pre-service teachers in order for them to utilize the Internet for the purpose of teaching in their classroom.

Bridging this idea which has been consistently discussed in this study, research question four intends to find out the relationship between the length of time teachers spent on the Internet towards their TPACK. Nonetheless, based on the results in Table 4 that addresses research question 4, pre-service teachers' TPACK is significantly related to the time used on the Internet. Relating to the previous findings on the time spent towards their confidence in use, this shows that the TPACK of the pre-service teachers' are affected by the amount of time spent on the Internet, which unfortunately will not affect their confidence to use ICT in class. These findings support the fact that TPACK is an innate personal factor which is highly dependent on the individual's cognitive abilities. As these pre-service teachers interact with the environment or the context that they have to practice their teaching pedagogy, this innate personal factor may be hindered due to expectations that could thus affect their confidence. This is an aspect that should be addressed since the pre-service teachers are yet to be appointed as teachers. If pre-service teachers are having such beliefs in their teaching, it would pose as a continuous issue to the education system in bringing in the Information Age into classrooms.

\section{Conclusion}

This study is carried out within the limitations where data was collected from samples born in the 1990s which is 10 years after the digital boom. The cognition of all pre-service teachers would constantly change in terms of their exposure as students in schools due to the various policies and development in terms of ICT in or out of class. Hence, once they enter to be trained as pre-service teachers, their knowledge in terms of ICT would be different than their trained peers who are working in schools or that of their students. Pre-service teachers today and the society in general are believed to be heavy consumers of the Internet as an abundance of information is just a tap away on their gadgets. But, who knows what would happen to the field of ICT in future and because of that, how education and schools in general should cater to these rapid changes in order to ensure the teachers who are trained for their profession remain relevant. Since ICT today have evolved a lot compared to the 1980 s, there needs to be an emphasis on the training for pre-service teachers with regards to the approaches and instructional methods to teach ICT in class. This is because while pre-service teachers are avid users of the Internet, there is no relationship of their knowledge towards teaching in the classroom. Thus, there is a need for the various institutions to develop training courses that befits the demands of the education.

For future studies, there should be more focus on the instructional aspects within the TPACK that could be used to investigate the confidence and viability of ICT in language classrooms. A more developed research that looks on pre-service teachers and their technological knowledge towards integrating the content of language and the use of the different Internet or ICT applications offered should be investigated further. In fact, research using a qualitative 
approach should be conducted to seek a deeper understanding of the present scenario in the usage of ICT in classrooms should be conducted in future studies. By having literature from both quantitative and qualitative formats, the issue can be studied further in depth and thus, would assist stakeholders to make decisions and policies that matches the current teaching and learning trend. Moreover, since ICT is progressing at a pace that could be challenging to upkeep, other aspects that are related towards technology in education should be given much thought for study such as the financial aspect and change in the mindset. This is because the setting of the school where these pre-service teachers are to render their professional knowledge would be different, from one context to another. This is due to the fact that Malaysia as a nation, although is progressing towards becoming a developed country economically, is unique because of the geographical, cultural and social differences.

\section{References}

Abd. Rahim, B., \& Shamsiah, M. (2008). Teaching using information communication technology: Do trainee teachers have the confidence? International Journal of Education and Development using ICT, 4(1), 5-12. Retrieved from http://www.editlib.org/d/42210

Bandura, A. (1989). Social cognitive theory. In R. Vasta (Ed.). Annals of child development: Six theories of child development, 6, 1-60. Greenwich, CT: JAI Press.

Churchill, D. (2009). Literacy in the web 2.0 world: New literacy. [PowerPoint slides]. Retrieved from http://www.slideshare.net/zvezdan/new-literacy-in-the-web-20-world.

Dudeney, G., \& Hockly, N. (2008). How to teach English with technology. Edinburgh: Pearson.

Gill, L., Dalgarno, B., \& Carlson, L. (2015). How does pre-service teacher preparedness to use ICTs for learning and teaching develop through their degree program? Australian Journal of Teacher Education, 40(1), 35-59. http://dx.doi.org/10.14221/ajte.2015v40n1.3

Hafizoah, K., Haslinda, H., \& Noor Raha, M. D. (2005). The effectiveness of using ICT in enhancing language learning. Paper Presented at the Inaugural International Conference of Teaching and Learning of English: Towards an Asian Perspective.

Harris, J., Grandgenett, N., \& Hofer, M. (2010). Testing a TPACK-Based Technology Integration Assessment Rubric. Paper presented at the Society for Information Technology \& Teacher Education International Conference 2010, San Diego, CA, USA. Retrieved from http://www.editlib.org/p/33978

Hashemi, B. (2013). The investigation of factors affecting the adoption of ICTs among English language teachers in ESL context. International Journal of Language Learning and Applied Linguistics World, 58. Retrieved from http://www.ijllalw.org/finalversion415.pdf

Kadel, R. (2005). How teacher attitudes affect ICT integration. Learning and Leading with ICT, 32(5), 34-35 \& 47. In Majocha, E. (2015). Passage through the threshold of technological 
change: Insights into leading qualities of a teacher. Rotterdam, The Netherlands: Sense Publishers.

Kirsch, I., Braun, H., Yamamoto, K., \& Sum, A. (2007). America's perfect storm: Three forces changing our nation's future. Princeton: Educational Testing Service.

Kirschner, P. and Woperies, I.G.J.H. (2003). Mind tools for teacher communities: A European perspective. ICT, Pedagogy, and Education, 12(1), 127-149. Retrieved from http://www.triangle.co.uk/jit/

Lankshear, C., \& Knobel, M. (2011). New literacies: Everyday practices and social learning. New York: Open University Press.

Leu, D. J., McVerry, J. G., O’ Byrne, W. I., Kiili, C., Zawalinski, L., Everett-Cacopardo, H., Kennedy, C., \& Forzani, E., (2011). The new literacies of online reading comprehension: Expanding the literacy and learning curriculum. Journal of Adolescent \& Adult Literacy, 55(1), 5-14. http://dx.doi.org/10.1598/JAAL.55.1.1

Marginson, S., \& Rhoades, G. (2002). Beyond National States, Markets, and Systems of Higher Education: A Glonacal Agency Heuristic. Higher Education, 43(3), 281-309. In Huisman, J., \& Tight, M. (2013). Theory and method in higher education research. The UK: Emerald Group Publishing Limited.

Melor Md Yunus. (2007). Malaysian ESL teachers' use of ICT in their classrooms: Expectations and realities. European Association for Computer Assisted Language Learning. ReCALL, 19(1), 79-95. Retrieved from http://journals.cambridge.org/abstract_S0958344007000614

Moganashwari Kandasamy, \& Parilah Haji Mohd Shah. (2013). Knowledge, attitude and the use of ICT among ESL teachers. Proceeding of the Global Summit on Education 2013. Retrieved from http://worldconferences.net/proceedings/gse2013/papers_gse2013/247220Moganashwari\%20 KandasamyParilah\%20Bt\%20Hj.\%20Mohd\%20Shah.pdf

Piaget, J. (1968). On the development of memory and identity. Barre: University Press.

Pierson, M. E. (2001). ICT Integration Practice as a Function of Pedagogical Expertise. Journal of Research on Computing In Education, 33(4), 413. Retrieved from https://www.learntechlib.org/p/94569

Prensky, M. (2001). Digital natives, digital immigrants. On the Horizon, 9(5). Retrieved from http://www.emeraldinsight.com/doi/pdfplus/10.1108/10748120110424816

Samuel, R. J., \& Zaitun, A. B (2007). Do teachers have adequate ICT resources and the right ICT skills in integrating ICT tools in the teaching and learning of English language in Malaysian schools? The Electronic Journal on Information Systems in Developing Countries (EJISDC), 29(2), 1-15. Retrieved from http://www.ejisdc.org/ojs2/index.php/ejisdc/article/view/283 


\section{Macrothink}

Spazak, L. (2013). Secondary preservice teachers' perception of preparedness to integrate ICT (Unpublished doctoral dissertation). Indiana University of Pennsylvania, Indiana, The United States.

Teo, T., Wong, S. L., Chai, C. S. (2008). A cross-cultural examination of the intention to use technology between Singaporean and Malaysian pre-service teachers: An application of the ICT Acceptance Model (TAM). Educational ICT \& Society, 11(4), 265-280. Retrieved from http://www.ifets.info/journals/11_4/19.pdf

Thomas, A., \& Stratton, G. (2006). What are we really doing with ICT in physical education: A national audit of equipment, use, teacher attitudes, support, and training. British Journal of Educational ICT, 37(4), 617-632. http://dx.doi.org/10.1111/j.1467-8535.2006.00520.x

Wong, S. L., Ng, S. F., Mokhtar, N. \& Tang, S. H. (2005). Experienced and inexperienced internet users among pre-service teachers: Their use and attitudes toward the Internet. Journal of Educational ICT \& Society, 8(1), 90-103. Retrieved from http://www.ifets.info/journals/8_1/12.pdf

\section{Copyright Disclaimer}

Copyright for this article is retained by the author(s), with first publication rights granted to the journal.

This is an open-access article distributed under the terms and conditions of the Creative Commons Attribution license (http://creativecommons.org/licenses/by/3.0/). 